\title{
Development of Quality Protein Maize (QPM) Inbred Lines and Genetic Diversity Assessed with ISSR Markers in a Maize Breeding Program
}

\author{
K. Mbuya ${ }^{1,2}$, K. K. Nkongolo ${ }^{3^{*}}$, R. Narendrula ${ }^{3}$, A. Kalonji-Mbuyi $i^{1,4}$ \\ and R. V. Kizungu ${ }^{1,2}$ \\ ${ }^{1}$ Faculty of Agronomy, University of Kinshasa, B.P 117, Kinshasa 11, RD-Congo. \\ ${ }^{2}$ National Institute for Research and Agronomic Studies (INERA), B.P. 2037, Kinshasa 1, \\ $R D$ - Congo. \\ ${ }^{3}$ Department of Biological Sciences, Laurentian University, Sudbury, Ontario, Canada, P3E \\ $3 C 6$. \\ ${ }^{4}$ Regional Nuclear Energy Center, Kinshasa (CRENK), RD-Congo.
}

\begin{abstract}
Authors' contributions
This work was carried out in collaboration between all authors. KM initiated the study, developed the inbred lines, conducted field trials, analyzed the data and prepared the draft manuscript. KKN supervised the molecular analyses, integrated the field and the laboratory data, and wrote the final draft of the manuscript. RN carried out the molecular studies. AK-M

monitored the field trials. RVK monitored the experimental designs and the statistical analysis of agronomic data. All authors read and approved the final manuscript.
\end{abstract}

Research Article

Received $8^{\text {th }}$ June 2012 Accepted $1^{\text {st }}$ October 2012 Published $2^{\text {nd }}$ November 2012

\section{ABSTRACT}

Very few studies have been conducted to develop new quality protein maize (QPM) varieties adapted to various agro-ecological conditions in Africa. Such QPM varieties with high grain yield, genes for resistance to local disease and pests would contribute to increased grain production and to alleviate poverty and malnutrition. During the first step of the QPM breeding program in the DR-Congo, 137 inbred lines were developed and selected in the field based on various agro-morphometric characteristics. Molecular analysis revealed high level of genetic variability among inbreds. The level of polymorphic loci observed with ISSR markers varied between $74 \%$ and $80 \%$. Nei's gene diversity and Shannon's information index values varied from 0.22 to 0.27 and from 0.34 to 0.41 ,

*Corresponding author: Email: knkongolo@laurentian.ca; 
respectively. The majority of inbred lines were distantly related. In fact, more than $87 \%$ of genetic distance values were above 0.50 . The genetic distance values among the different parental maize accessions varied from 0.39 to 0.72 . Inbred lines from the same parental accession were also not genetically close with genetic distance values varying from 0.28 to 0.59. More importantly, the ISSR data are useful in the selection of inbred lines to be tested for general and specific combining abilities and further development of synthetics.

Keywords: Quality protein maize (QPM); DR-Congo; inbreds; ISSR; genetic variability.

\section{INTRODUCTION}

Maize is a major staple food and an important source of protein accounting for up to $60 \%$ of the daily human protein supply (Musila et al., 2010; Sofi et al., 2009). Normal maize varieties are deficient to two amino acids, lysine and tryptophan that are nutritionally essential for humans (Gaziola et al., 1999; Krinavek et al., 2007; Sofi et al., 2009; Azevedo and Arruda, 2010; Mbuya et al., 2011). Maize mutants for high lysine and tryptophan have been reported in several studies. Likewise, lysine metabolism and endosperm protein synthesis in maize mutants are well documented in various reports (Azevedo et al., 2003; Azevedo et al., 2004). The lysine and tryptophan content in normal maize varieties is less than a half of the recommended rate for human nutrition (FAO/WHO-Expert consultation, 1990). This problem has been addressed through research breakthroughs at CIMMYT in the late 1990's that lead to the development of quality protein maize (QPM) that content twice the amount of lysine and tryptophan (Krivanek et al., 2007). Since then over 20 African countries have adopted and promoted QPM in their agricultural development plan (Mbuya et al., 2010). The majority of these national programs limit their breeding effort to evaluating and selecting from international germplasms QPM varieties already released. Because of variations in climate and regional needs, QPM adapted varieties designed for local applications need to be developed.

The development of inbred lines is the first step in maize hybrid, synthetic and composite population production. Inbreds are also extensively used for the development of linkage maps (Burr et al., 1988), quantitative trait locus mapping (Austin, 2001), molecular evolution (Ching et al., 2002), developmental and physiological genetics (Fowler and Freeling, 1996; Crosbie et al., 1978) as well as phenotype-genotype association analyses and estimation of linkage disequilibrium in maize (Thornsberry et al., 2001; Remington et al., 2001; Liu et al., 2003). Synthetic varieties can be produced by random intermating of six to twelve S1, S2, or S3 inbred lines selected for general combining ability (GCA). The main purpose of an early testing is to eliminate lines or populations (before making testcrosses) that do not merit consideration for further inbreeding and selection (Carlone et al., 1988; Horner et al., 1989; Venkatesh et al., 2001).

Assessing genetic variability of inbred lines is essential in identifying the best parental combinations for creating hybrids, synthetic and composite populations superior and with significantly higher yield compared to their parents. Inbreds can also be useful in describing heterogroups and defining core subsets selected for specific traits and for estimating possible loss of genetic variation during selection or conservation process (Lu et al., 2009; Melchinger et al., 1990; Reif et al., 2003a and b; Mohammadi and Prasanna, 2003; Reif et al., 2005). 
There are several molecular markers used for plant genetic analysis. Each one of these marker systems offers a unique combination of advantages and disadvantages (Kumar et al., 2009). They differ in the type of sequence polymorphism detected, the information content, the dominance relationships between alleles, the amount of DNA required, the need for DNA sequence information in the species under analysis, the development costs, the ease of use and the extent to which they can be automated (Kumar et al., 2009). The choice of marker systems is to significant extent dictated by the specific application and there is probably not a single class of markers that can satisfy all the needs encountered by plant geneticists and breeders. ISSR markers are widely used for study of plants and have been shown to be useful in genetic fingerprinting and genetic diversity analysis of many species of plants and animals. ISSR system detects polymorphism in inter-microsatellite loci, using a primer designed from dinucleotide or trinucleotide simple sequence repeats (Zietkiewicz et al., 1984; Kumar et al., 2009). Compared with other molecular marker such as RAPD, AFLP and SSR, the ISSR marker has its specific advantages. These include, no prior sequence information required; the method is simple, quick, and amenable to laboratory level; the abundance of genomic information; the use of radioactivity is not required; and the ISSR primers generated a high level of polymorphism (Zietkiewicz et al., 1984; Kumar et al., 2009).

The main objectives of the present study were 1) to develop quality protein maize inbred lines for breeding applications and 2) to characterize genetic variation among them using ISSR markers.

\section{MATERIALS AND METHODS}

\subsection{Inbred Development Method}

Inbred lines have been developed by inbreeding selected heterozygous plants from five selected varieties (Katoki wa Lukasa, MUS-1, GPS-5, Mudishi-1, and Mudishi-3). These varieties were selected because of their different and complementary agronomic attributes including, disease resistance, grain yield, date of maturity, etc.. For each populations, the selected plants (S0) were hand-pollinated and pedigree selection was practiced. The pedigree method was used for maize inbred lines development. This method consists essentially of selfing the individual plants selected. One best ear from each variety was planted using ear-to-row method at $0.75 \mathrm{~m} \times 0.25 \mathrm{~m}$ with one plant per hill in a separate block of selfing. Fertilizers were applied based on local recommended rate (64-46-0). Prior to the initiation of flowering, plants to be hand pollinated were checked daily for signs of ear shoot emergence and pollen shedding. Before the silks emerge, the ear shoot on the plant to be pollinated was covered with a semitransparent shoot bag anchored securely against the stalk to prevent dislodging by wind or rain. While doing that, care was taken to leave enough space between the shoot tip and the shoot bag to allow silks to develop properly.

About 24 hours prior to pollination, the tassel already shedding pollen was covered with a tassel bag (pollinating bag) secured with a paper clip. On the day of pollination, the covered tassel was lightly shacked inside the tassel bag to dislodge pollen and the tassel bag containing pollen was then unstapled and carefully removed and emptied over the exposed silks. Finally, the tassel bag was placed over the pollinated shoot and stapled and remained in place until harvest to avoid undesirable probable pollen. 
The selection of desirable genotypes was done during growth stage and at harvest based on different agro-morphological criteria. Vigorous plants resistant to maize downy mildiew, streak virus and stem borers were selected. Short genotypes with low position of ears on the plants were preferred. Lines with cobs with abnormal shape and with few kernels were discarded. Inbred lines with few kernels per cob and cob with abnormal shape, non-straight kernel per row, chalky kernels, and high level of husk exposed tips were not selected. Likewise, rotten ears were also discarded. Selected ears were planted the following season using the same scheme above described up to S2 stage.

\subsection{DNA Extraction}

The total cellular DNA from individual samples was extracted from seedling tissue using the method described by Mehes et al. (2007) with some modifications. The modification involved addition of PVP (polyvinylpyrrolidone) and $\beta$-mercaptoethanol to the CTAB extraction buffer. The DNA concentration was determined using the fluorochrome Hoechst 33258 (bisbensimide) fluorescent DNA quantitation kit from Bio-Rad (cat. \# 170-2480) and the purity was determined using a spectrophotometer (Varian Cary 100 UV-VIS spectrophotometer).

\subsection{ISSR Analysis}

The ISSR amplification was carried out in accordance with the method described by Nagaoka and Ogihara, 1997; with some modifications described by Mehes et al., 2007; Nkongolo et al., 2011. All DNA samples were primed with each of the ten primers used (Table 1). All PCR products were loaded into $2 \%$ agarose gel in $1 X$ Tris-Borate-EDTA (TBE) buffer. Gels were pre-stained with 4 I of ethidium bromide and run at $3.14 \mathrm{~V} / \mathrm{cm}$ for approximately 120 minutes. These agarose gels were visualized under UV light source, documented with the Bio-Rad ChemiDoc XRS system and analyzed for band presence or absence with the Discovery Series Quantity One 1D Analysis Software. The resulting data matrix of the ISSR phenotype was analyzed using POPGENE software (version 1.32) to estimate genetic diversity parameters (Yeh and Boy, 1997). The genetic distances were calculated using Jaccard's similarity coefficient estimated with the RAP Distance program version 1.04 (Armstrong et al., 2005).

\section{RESULTS AND DISCUSSION}

\subsection{Inbred Development}

Developing inbreds, which exhibit desirable characteristics, is the first step of maize field breeding for producing hybrids and synthetics. During this phase, the seeds from the best plants in the best rows are selected and planted for the next generation of testing. Once excellent inbreds are identified, the second major task consisted in identifying combinations of parental inbred lines that produce the highest-yielding variety. Proper selection of inbreds for parent lines is critical to developing consistent, top-performing products. During early parent line development, each plant possesses different combinations of genes, resulting in various combinations of traits that respond differently to environmental stresses. Parental varieties used for inbred development are described in Table 1. 
Table 1. Description of varieties selected for inbred development

\begin{tabular}{ll}
\hline Varieties & Agronomic traits of interest \\
\hline KATOKI WA LUKASA & $\begin{array}{l}\text { Downy mildew resistance, ability of filling farmers sale measure } \\
\text { with less ears, yield, earliness, better adaptation for season B }\end{array}$ \\
MUS-1 & Downy mildew resistance, yield, better adaptation for season B \\
GPS-5 & Yield, better adaptation for season B \\
MUDISHI 1 & $\begin{array}{l}\text { High yield, high lysine and tryptophan content } \\
\text { Downy mildew resistance, yield, high lysine and tryptophan } \\
\text { MUDISHI 3 }\end{array}$ \\
\hline
\end{tabular}

In the present study, we have developed 137 inbred lines named Gandajika maize lines (GML) that include 56 from normal maize varieties adapted to local conditions of southern DR-Congo and 81 QPM inbreds from the two newly released varieties (Mudishi 1 and Mudishi 3). These lines represent the basis from which new elite inbred lines will be selected for maize synthetic and composite populations following the tests for general and specific combining abilities.

Different methods for maize inbred production can be used in a breeding program. The most commonly used include the recurrent, the pedigree, and single seed descent selection methods, within family full-sib mating. Double haploid method can be used to shorten the inbreeding process. In the present study, the pedigree method was preferred to other approach as it is easy to manage in the field in a context of low resource breeding program. This method that is based on self-pollination is a rapid approach towards homozygosity (Hallauer and Miranda, 1988) compared to full-sib mating. Lee and Kannenberg (2004) compared these two methods and reported that the inbred lines developed through fullsibling had significantly higher grain yields and lower grain moisture, as well as a significantly greater percentage of broken stalks. The self pollination method produced hybrids with higher test weights and lower percentage of broken stalks. In the present study, significant variation among the new QPM inbreds was found. Similar results were reported by Bhatnagar et al. (2004); Musila et al. (2010) who observed a disparity in performance among and between QPM inbreds lines for grain yield, root lodging and stalk lodging.

In the present study, early generation (S1 and S2) testing was used to short cut the production of synthetic populations. Testing of inbred lines in early generations for example $\mathrm{S} 1$, may prove to be more effective than in the later generations. The ultimate goal of various breeding methods in maize is the production of improved genotypes. Hence short cut but efficient methods are needed for isolation and identification of superior genotypes which can be used in hybrid breeding programs. For selection of inbred lines tolerant to inbreeding depression and being superior in genetic potential, early generation testing is desirable. In early generation testing, S1 or second generation of selfed progeny (S2) are out crossed to a common tester for yield and general performance. Lines with poor combing abilities are discarded and only good performance lines are further selfed and selected in subsequent cycles of selection (Barata and Carena, 2006; Rahmani et al., 2010). To accelerate the development of synthetics, it is important to determine the usefulness of the available QPM inbred lines in cross with testers through combining ability studies. General combining ability is tested by crossing with one or two testers. This represents 137 to 274 singles crosses for 
the inbreds produced in the present study. The specific combining ability on the other hand indicates the ability of inbred lines to combine in specific single, three-way, and double crosses (Bhatnagar et al., 2004; Musila et al., 2010). Although top crosses can be made to narrow the number of inbreds to be tested for specific combining ability, the total number of crosses and the progenies to be evaluated are still too laborious and expensive. Molecular breeding has been proven as a valuable approach to reducing variety development cycle.

\subsection{Molecular Analysis}

Four ISSR primers that produced consistently strong amplification products were selected among the 20 primers tested. They include ISSR primers 17898A, 17898b, HB15, and UBC841 (Table 2). An example of amplification products with primer 17898B is deplicted in Fig. 1. The high level of genetic variability was confirmed by molecular analysis. In fact, the level of polymorphic loci observed with ISSR markers were $74 \%, 75 \%$, and $80 \%$ for MUS-1, S1-Mudishi 3 and S2-Mudishi 3 respectively. Nei's gene diversity and Shannon's information index values varied from 0.22 to 0.27 and from 0.34 to 0.41 , respectively (Table 3 ). Similar levels of polymorphic loci was observed when parental QPM and normal maize varieties were analyzed using ISSR (Nkongolo et al., 2011); Liu et al. (2003) used microsatellite markers to characterize 260 normal inbred lines from the United States, Europe, Canada, South Africa, and Thailand. They found high levels of genetic diversity among maize inbred lines. Li et al. (2006) on the other hand, reported that Chinese normal and QPM inbred lines had a narrower genetic diversity than CIMMYT QPM inbred lines based on microsatellite analysis. This is likely ascribed to the larger size of the CIMMYT maize gene pool compared to the Chinese maize collection.

The genetic relatedness among accessions was determined using Jaccard's similarity coefficients. The scale used for the genetic distance runs from 0 (meaning no genetic difference) to 1 (different for all conditions -criteria). The genetic distance among the different series of maize accessions varied from 0.39 to 0.72 (Table 4). Mudishi-3-S1 and Mudishi -1-S1 were the most distantly related while GML Mudishi 3-S2 and MUS-1 were the most closely related (Table 4). Moreover $87 \%$ of genetic distance values were above 0.50 . Genetic relatedness within Mudishi 3 was analyzed in details. For S1 and S2 of Mudishi 3, the genetic distance values among GML inbreds vary from 0.28 to 0.59 (Tables 5 and 6). For Mudishi 3 -S1, GML - 333 and GML 325 were the most closely related and for Mudishi 3 S2, the closest inbreds were GML 302 and GML 303 (Table 5). Inbreds GML 334 and GLM 325 were the most distantly related for Mudishi 3 - S2 and GML 334 and 325 for Mudishi 3S1 (Table 6). Dendrograms were constructed from the similarity coefficients using RAPDistance program v. 10.4. (Fig. 2 to 4). Mudishi 3- S2 was separated from the other accessions with a high degree of confidence (booth strap of 100) and Mudishi 1 - S1 clustered with Katoki wa lukasa with a bootstrap of 50 (Fig. 2). GML GPS-5-514 was separated from GPS-5 - 501 and GML GPS-5-505 with high degree of confidence (bootstrap 100, data not shown). Likewise GML - Katoki wa Lukasa 1-219 was separated from two clusters with a bootstrap value of 100 while GML Katoki wa Lukasa 221 and GML Katoki wa Lukasa 222 clustered together with a bootstrap of 70. For MUS-1, GML MUS-1126 was separated from other inbreds with high level of support (bootstrap 100). The pairs of inbreds that cluster together with an acceptable level of support were GML MUS-1- 108 and GML MUS-1-130, GML MUS-1-118 and GML MUS-1- 133, and GML MUS-1-113 and GML MUS-1-16. For Mudishi 1 two main clusters were identified, GML Mudishi 1- 405 and GMLMudishi 1-407 cluster together as well as GML Mudishi-1-401 and GML Mudishi 1-408. Details of the inbred clustering for Mudishi 3 S1 and S2 are presented in Fig. 3 and 4. For 
Mudishi 3 S1, GML Mudishi 3- 313 was an out-group while the other inbreds formed one main cluster (Fig. 3). The other pairs that clustered with a high degree of confidence include GML 3-327 and GML Mudishi 3-340 (bootstrap 58), GML-Mudishi 3 -331 and GML Mudishi 3-335 (Bootstrap 66), GML Mudishi 3-321 and GML Mudishi 3-332 (bootstrap 55), and GML Mudishi 3-325 and GML Mudishi 3-333 (Bootstrap 60) (Fig. 3). For Mudishi 3 - S2, two main clusters were identified with a high degree of confidence (bootstrap 100) (Fig. 4). Within the two groups, the pairs of GML that cluster together with a relatively high degree of confidence include GML Mudishi 3-302 and GML Mudishi 3303 (Bootstrap of 70) and GML Mudishi 3322 and GML Mudishi 3 -322 and GML Mudishi 3-324 (Bootstrap of 55) (Fig. 4). .

In general both the genetic variation and distances among the investigated varieties were high. The genetic variation within accessions was also relatively high which was expected for an open pollinated species. The high level of genetic variations among the inbreds within the same varieties despite the inbreeding through self pollination is indicative of a number of genes for the traits targeted during inbred development (yield, disease resistance, height etc.). This is consistent with many other studies. Musila et al. (2010); Bhatnagar et al. (2004) reported the preponderance of additive gene action for grain yield, root and stalk lodging. The high level of genetic distance among the inbred lines indicates the uniqueness of the majority of the inbreds developed in this breeding program. These results are consistent with Segmagn et al., 2012 who reported high levels of genetic distances in CIMMYT normal maize inbred lines from eastern and southern Africa using SSR markers.

Genetic distance estimates can be useful in identifying inbreds that are genetically distant to develop synthetics or composite maize lines that carry a high variability of genes. Such information can significantly reduce the number of lines for field evaluations and shorten the variety development cycle. General experience showed that crosses of unrelated genotypes contributed to greater yields. In general, better hybrids involved inbreds lines derived from two or more genetic background (Hallauer and Malithano, 1976). Because of great expenditure of time and money in development, maintenance and evaluation of inbred lines, the application of molecular approach is a valuable tool in early selection of inbreds before testing for general and specific abilities.

Several types of molecular markers including restriction fragment length polymorphism (RFLP), amplified fragment length polymorphism (AFLP), simple sequence repeats (SSRs), ISSR, RAP, and single nucleotide polymorphisms (SNPs) can be used to assess the level of genetic variability. In the present study, ISSR markers were preferred to other markers systems for this specific maize breeding program. ISSR marker system accesses variation in the numerous microsatellite regions dispersed throughout the genome (Bornet and Branchard, 2004) and circumvents the challenge of characterizing individual loci that other molecular approaches require. ISSR analysis involved amplification of regions between adjacent, inversely oriented microsatellites, using a simple sequence repeat (SSR) motif containing primers anchored at the 3' or 5' end by two or four arbitrary, often degenerate nucleotides (Zietkiewicz et al., 1994).

More importantly, ISSRS are randomly distributed throughout the genome. ISSR marker accesses variation in the numerous microsatellite regions dispersed throughout the various genomes (particularly the nuclear genome) and circumvents the challenge of characterizing individual loci that other molecular approaches require (Nagaoka and Ogihara, 1997; Bornet and Branchard, 2004; Kumar et al., 2009). 
Table 2. The nucleotide sequence of ISSR primers used to amplify DNA samples from corn

\begin{tabular}{lllll}
\hline $\begin{array}{l}\text { Primer } \\
\text { identification }\end{array}$ & Nucleotide sequence $\left(\mathbf{5}^{\left.\mathbf{\prime} \rightarrow \mathbf{3}^{\prime}\right)}\right.$ & $\begin{array}{l}\text { G+ C content } \\
\mathbf{( \% )}\end{array}$ & $\begin{array}{l}\text { Number of } \\
\text { fragments } \\
\text { generated }\end{array}$ & $\begin{array}{l}\text { Fragment } \\
\text { size range } \\
\text { (bp) }\end{array}$ \\
\hline $\begin{array}{ll}\text { ISSR Primers } \\
\text { 17899A }\end{array}$ & CAC ACA CAC ACA AG & 50.00 & 17 & $480-2080$ \\
$17898 B$ & CAC ACA CAC ACA GT & 50.00 & 25 & $203-2090$ \\
HB15 & GTG GTG GTG GC & 72.72 & 14 & $330-1940$ \\
UBC 841 & GAA GGA GAG AGA GAG AYC & 50.00 & 25 & $260-1920$ \\
\hline
\end{tabular}

Table 3. Genetic diversity parameters of maize varieties based on ISSR data (Popgene program)

\begin{tabular}{|c|c|c|c|c|c|}
\hline Accessions & $\mathrm{Na}$ & $\mathrm{Ne}$ & $\mathbf{h}$ & I & Polymorphism \\
\hline S2 MUS-1 & 1.7407 & 1.4316 & 0.2521 & 0.3788 & $74.07 \%$ \\
\hline S1 MUDISHI-3 & 1.7531 & 1.3647 & 0.2231 & 0.3449 & $75.31 \%$ \\
\hline S2 MUDISHI-3 & 1.8025 & 1.4550 & 0.2699 & 0.4064 & $80.25 \%$ \\
\hline \multicolumn{6}{|c|}{$\begin{array}{c}{ }^{*} \mathrm{Na}=\text { Observed number of alleles } \\
{ }^{*} \mathrm{Ne}=\text { Effective number of alleles. } \\
{ }^{*} h=\text { Nei's gene diversity } \\
{ }^{*} I=\text { Shannon's Information index. }\end{array}$} \\
\hline
\end{tabular}

Table 4. Distance matrix generated from ISSR data using the Jaccard's similarity coefficient analysis for 6 corn varieties (bulk population) (Free Tree Program)

\begin{tabular}{lllllll}
\hline & S2 GPS-5 & S1-KATO-KI* & S2MUS-1 & S1 MUDISHI-3 & S1 MUSIDHI-1 & S2 MUDISHI-3 \\
\hline S2 GPS-5 & 0.0000 & 0.5333 & 0.5417 & 0.5714 & 0.5714 & 0.5455 \\
S1 KATOKI* & & 0.0000 & 0.6333 & 0.6154 & 0.5161 & 0.5926 \\
S2MUS-1 & & & 0.0000 & 0.5000 & 0.5769 & 0.3889 \\
S1 MUDISHI-3 & & & & 0.0000 & 0.7200 & 0.4000 \\
S1 MUSIDHI-1 & & & & & 0.0000 & 0.5833 \\
S2 MUDISHI-3 & & & & & 0.0000 \\
\hline
\end{tabular}

${ }^{*}$ Full name of this variety is Katoki wa Lukasa 
Table 5. Distance matrix generated from ISSR data using the Jaccard's similarity coefficient analysis for QPM GML inbred lines from S1 Mudishi-3 (Free Tree Program)

\begin{tabular}{|c|c|c|c|c|c|c|c|c|c|c|c|c|c|c|c|}
\hline & 313 & 321 & 325 & 328 & 329 & 332 & 333 & 334 & 335 & 336 & 338 & 339 & 340 & 327 & 331 \\
\hline 313 & 0 & 0.39 & 0.36 & 0.48 & 0.45 & 0.53 & 0.43 & 0.49 & 0.50 & 0.47 & 0.43 & 0.48 & 0.49 & 0.58 & 0.50 \\
\hline 321 & & 0 & 0.35 & 0.53 & 0.46 & 0.34 & 0.44 & 0.52 & 0.53 & 0.55 & 0.54 & 0.56 & 0.54 & 0.50 & 0.65 \\
\hline 325 & & & 0 & 0.43 & 0.44 & 0.45 & 0.28 & 0.58 & 0.45 & 0.41 & 0.44 & 0.52 & 0.47 & 0.48 & 0.54 \\
\hline 328 & & & & 0 & 0.38 & 0.49 & 0.48 & 0.44 & 0.52 & 0.49 & 0.48 & 0.47 & 0.48 & 0.45 & 0.56 \\
\hline 329 & & & & & 0 & 0.37 & 0.39 & 0.45 & 0.46 & 0.46 & 0.38 & 0.43 & 0.48 & 0.46 & 0.52 \\
\hline 332 & & & & & & 0 & 0.44 & 0.47 & 0.45 & 0.48 & 0.43 & 0.46 & 0.53 & 0.45 & 0.60 \\
\hline 333 & & & & & & & 0 & 0.55 & 0.47 & 0.43 & 0.42 & 0.54 & 0.49 & 0.47 & 0.53 \\
\hline 334 & & & & & & & & 0 & 0.50 & 0.38 & 0.45 & 0.35 & 0.45 & 0.57 & 0.50 \\
\hline 335 & & & & & & & & & 0 & 0.51 & 0.38 & 0.37 & 0.38 & 0.48 & 0.34 \\
\hline 336 & & & & & & & & & & 0 & 0.42 & 0.40 & 0.50 & 0.55 & 0.47 \\
\hline 338 & & & & & & & & & & & 0 & 0.39 & 0.36 & 0.50 & 0.46 \\
\hline 339 & & & & & & & & & & & & 0 & 0.39 & 0.56 & 0.49 \\
\hline 340 & & & & & & & & & & & & & 0 & 0.33 & 0.41 \\
\hline 327 & & & & & & & & & & & & & & 0 & 0.55 \\
\hline 331 & & & & & & & & & & & & & & & 0 \\
\hline
\end{tabular}

The prefix for each inbred line is GML (Gandajika Maize Line). 
Table 6. Distance matrix generated from ISSR data using the Jaccard's similarity coefficient analysis for QPM - GML inbred lines from S2 Mudishi-3 (Free Tree Program)

\begin{tabular}{|c|c|c|c|c|c|c|c|c|c|c|c|c|c|c|}
\hline & 302 & 303 & 305 & 308 & 309 & 310 & 312 & 314 & 319 & 320 & 322 & 323 & 324 & 325 \\
\hline 302 & 0 & 0.28 & 0.37 & 0.43 & 0.51 & 0.46 & 0.45 & 0.46 & 0.48 & 0.51 & 0.42 & 0.50 & 0.59 & 0.44 \\
\hline 303 & & 0 & 0.35 & 0.47 & 0.53 & 0.48 & 0.41 & 0.51 & 0.47 & 0.38 & 0.38 & 0.46 & 0.51 & 0.40 \\
\hline 305 & & & 0 & 0.37 & 0.53 & 0.44 & 0.33 & 0.51 & 0.48 & 0.40 & 0.42 & 0.47 & 0.54 & 0.50 \\
\hline 308 & & & & 0 & 0.39 & 0.40 & 0.39 & 0.44 & 0.37 & 0.43 & 0.45 & 0.38 & 0.52 & 0.47 \\
\hline 309 & & & & & 0 & 0.41 & 0.53 & 0.52 & 0.39 & 0.39 & 0.45 & 0.50 & 0.46 & 0.52 \\
\hline 310 & & & & & & 0 & 0.46 & 0.47 & 0.49 & 0.41 & 0.37 & 0.36 & 0.47 & 0.45 \\
\hline 312 & & & & & & & 0 & 0.43 & 0.45 & 0.36 & 0.42 & 0.38 & 0.46 & 0.44 \\
\hline 314 & & & & & & & & 0 & 0.52 & 0.41 & 0.49 & 0.42 & 0.55 & 0.51 \\
\hline 319 & & & & & & & & & 0 & 0.39 & 0.39 & 0.50 & 0.49 & 0.47 \\
\hline 320 & & & & & & & & & & 0 & 0.36 & 0.35 & 0.41 & 0.42 \\
\hline 322 & & & & & & & & & & & 0 & 0.41 & 0.33 & 0.41 \\
\hline 323 & & & & & & & & & & & & 0 & 0.39 & 0.40 \\
\hline 324 & & & & & & & & & & & & & 0 & 0.48 \\
\hline 325 & & & & & & & & & & & & & & 0 \\
\hline
\end{tabular}

The prefix for each inbred line is GML (Gandajika Maize Line). 


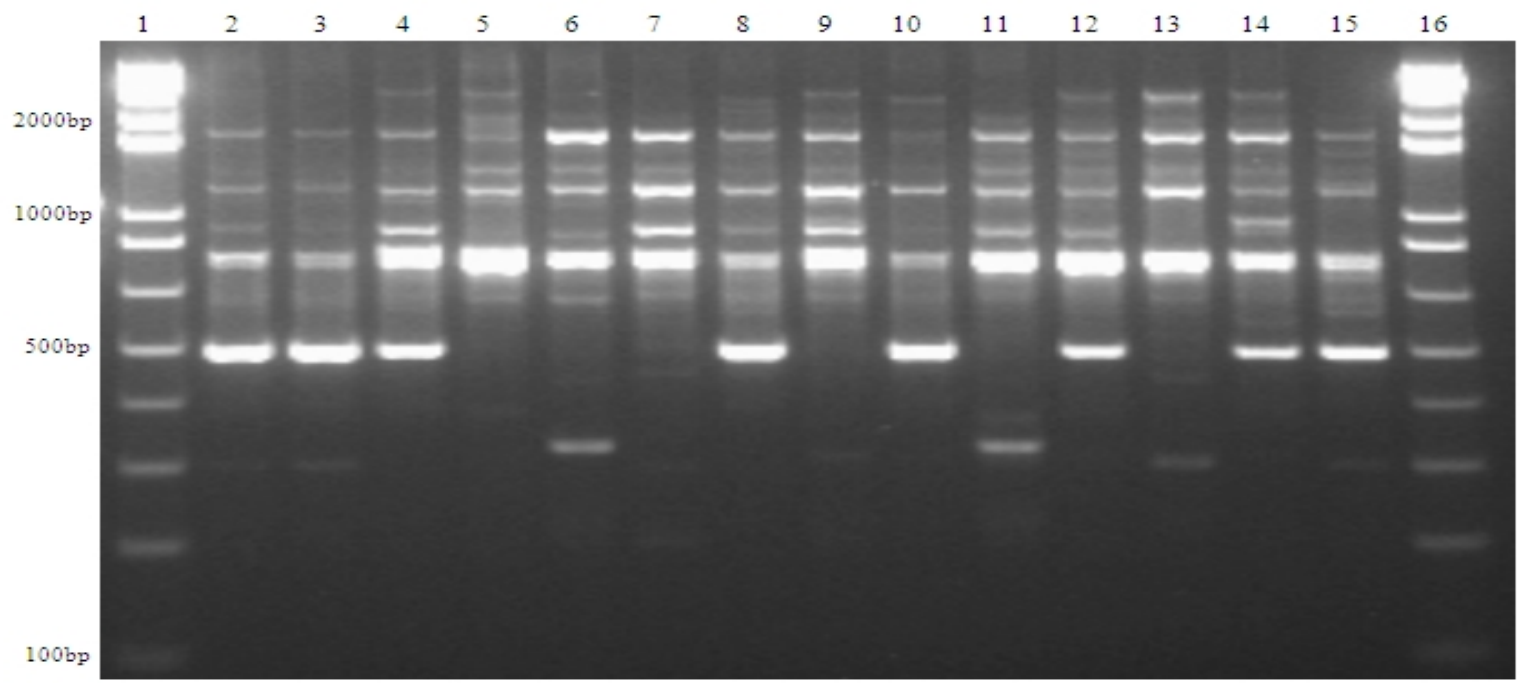

Fig. 1. ISSR amplification of corn samples with primer 17898B. Lanes 1 and 16 contain $1 \mathrm{~Kb}+$ ladder, lanes 2 to 15 contain samples from different QPM GML inbreds from S2

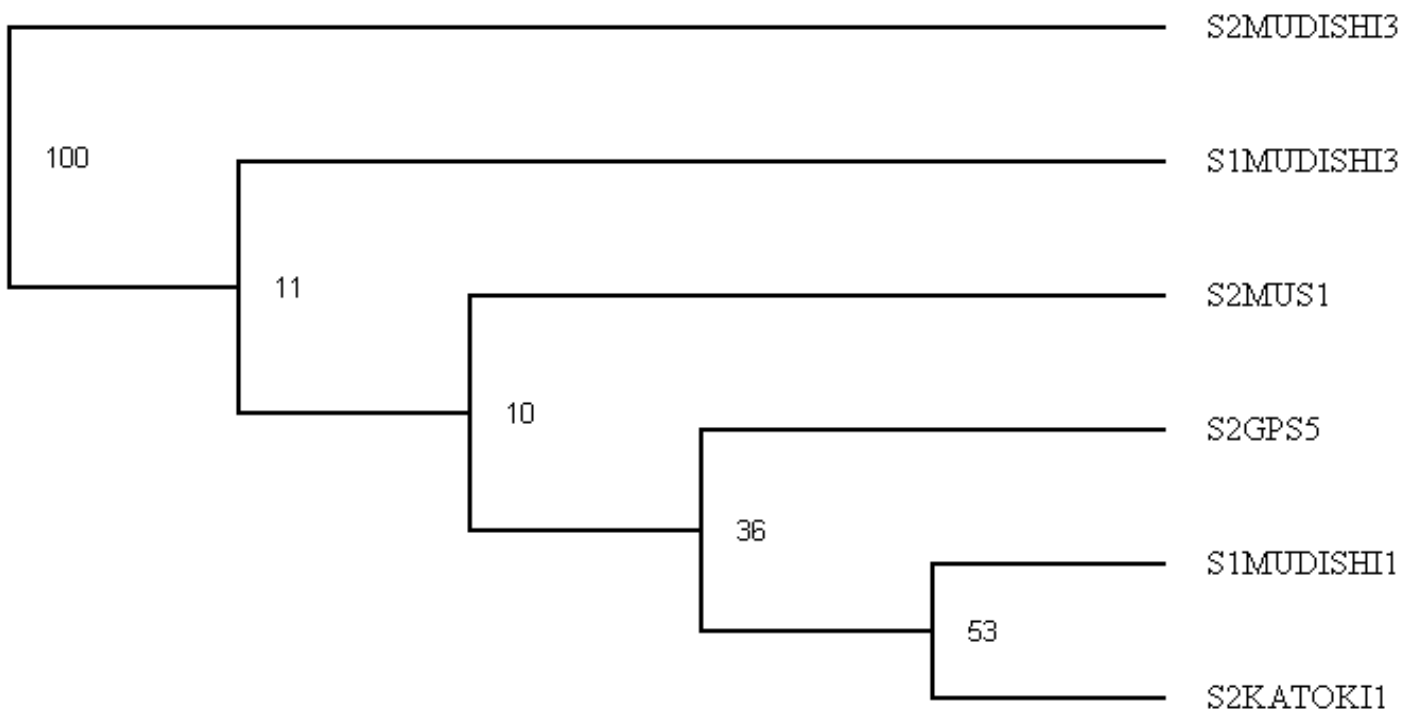

Fig. 2. Dendrogram based on ISSR data for six different maize parental line used for inbred development (Free Tree Program). 


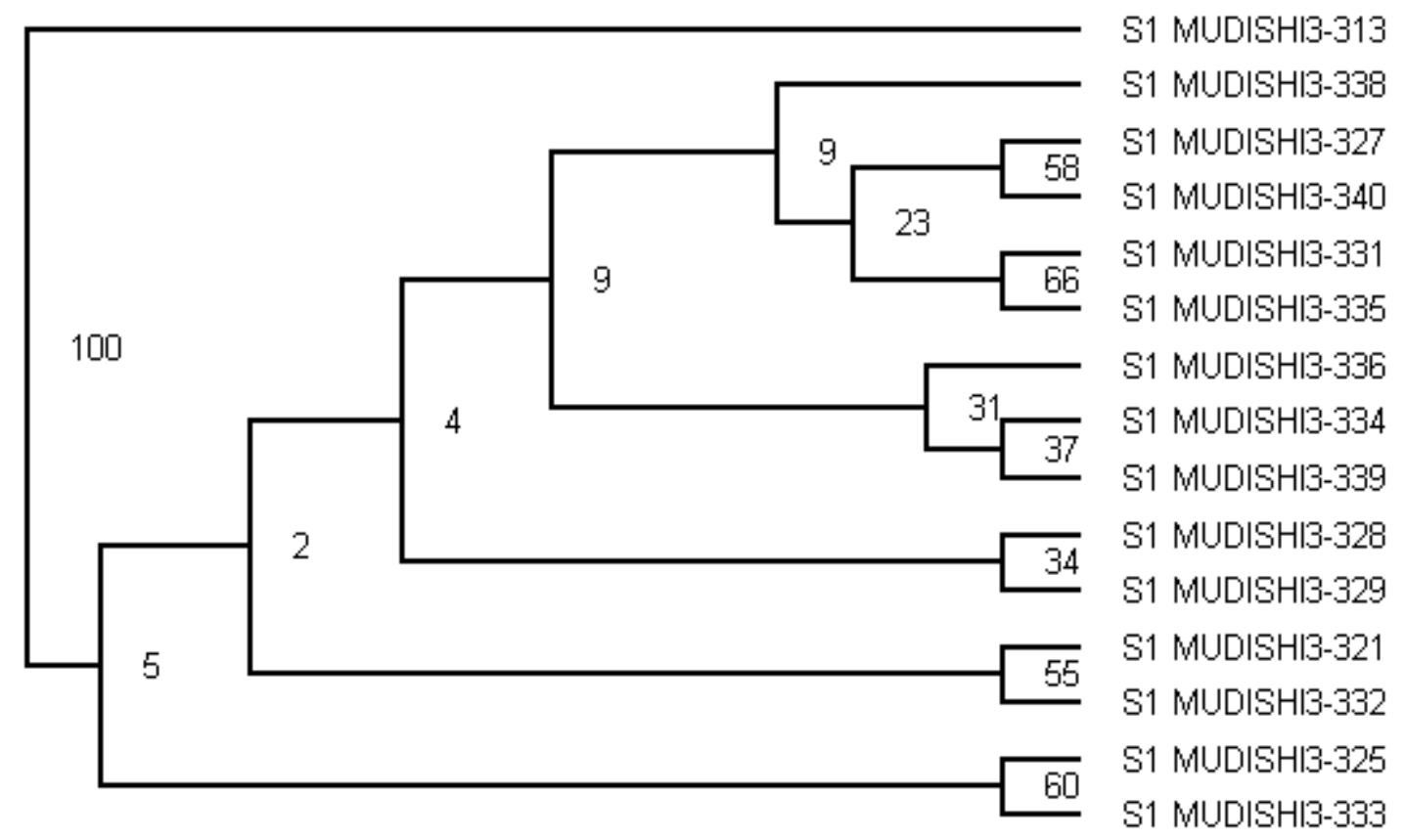

Fig. 3. Dendrogram based on ISSR data for different QPM GML inbred lines from S1 MUDISHI3 (Free Tree Program)

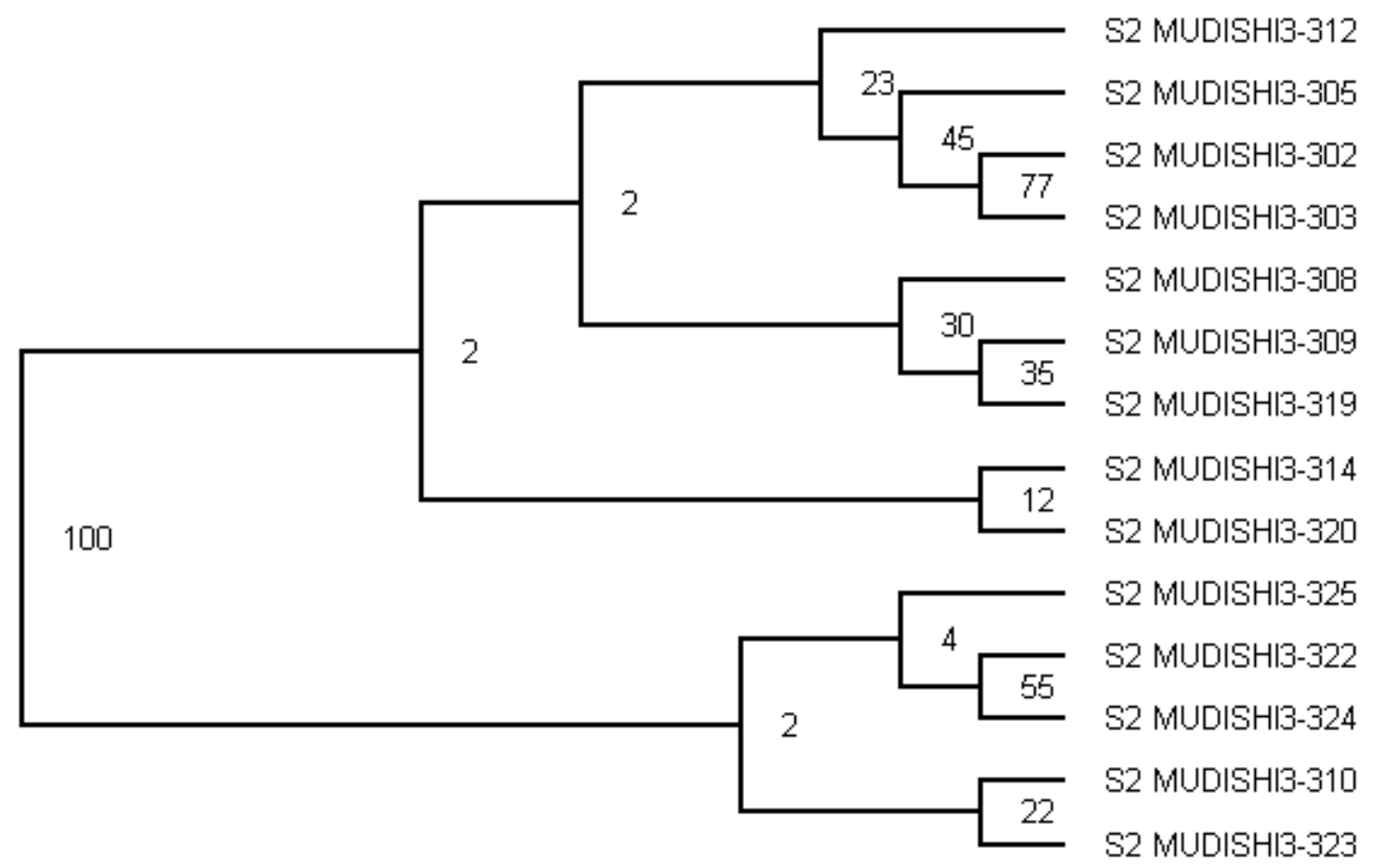

Fig. 4. Dendrogram based on ISSR data for different QPM GML lines inbred from S2 MUDISHI3 (Free Tree Program) 


\section{CONCLUSION}

Inbred QPM lines with potential to increase nutritional quality, yield, downy mildew and maize streak virus resistance were developed for the agro-savannah regions of DR-Congo. They could be used with other QPM inbreds to develop open pollinated varieties and to produce adapted synthetics. Molecular analysis revealed a high level of variability among and within the inbreds. More importantly, the ISSR data are useful in the selection of candidate inbreds for testing for general and specific combining abilities.

\section{ACKNOWLEDGEMENT}

This research was conducted through a partnership between Laurentian University (Ontario, Canada), University of Kinshasa (DR-Congo), and Caritas Congo. The authors are grateful to the Canadian International Development agency (CIDA) for financial support and the Association of Universities and Colleges of Canada (AUCC) for managing the partnership. We would like to express sincere gratitude to Caritas Development Mbuji-Mayi and INERA Gandajika for logistical arrangement.

\section{COMPETING INTERESTS}

Authors have declared that no competing interests exist.

\section{REFERENCES}

Armstrong, J.S., Gibbs, A.J., Peakall, R., Weiller, G. (2005). The RAP distance package. 2005, May/20, 30.

Austin, D.F., Lee, M., Veldboom, L.R. (2001). Genetic mapping in maize with hybrid progeny across testers and generations: plant height and flowering. Theor. Appl. Genet., 102, 163-176.

Azevedo, R.A., Damerval, C., Landry, J., Lea, P.J., Bellatoo, C.M., Meinhardt, L.W., Le Guilloux, M., Delhaye, S., Toro, A.A., Gaziola, S.A., Berdejo, B.D.A. (2003). Regulation of maize lysine metabolism and endosperm protein synthesis by opaque and floury mutations. Eur. J. Biochem., 270, 4898-4908.

Azevedo, R.A., Lea, P.J., Damerval, C., Landry, J., Bellato, C.M., Meinhardt, L.W., Le Guilloux, M., Delhaye, S., Varisi, V.A., Gaziola, S.A., Gratao, P.L., Toro, A.A. (2004). Regulation of lysine metabolism and endosperm protein synthesis by the opaque- 5 and opaque-7 maize mutations. J. Agric. Food Chem., 52, 4865-4871.

Azevedo, R.A., Arruda, P. (2010). High lysine maize: the key discoveries that have made it possible. Amino Acids, 39, 979-989.

Barata, C., Carena, M.J. (2006). Classification of North Dakota maize inbred lines into heterotic groups based on molecular and testcross data. Euphytica, 151 (3), 339-349.

Bhatnagar, S., Betran, F.J., Rooney, L.W. (2004). Combining abilities of quality protein maize inbreds. Crop Sci., 44, 1997-2005.

Bornet, B., Branchard, M. (2004). Use of ISSR fingerprints to detect microsatellites and genetic diversity in several related Brassica taxa and Arabidopsis thaliana. Hereditas, $140(3), 245-8$.

Burr, B., Burr, F.A., Thompson, K.H., Albertson, M.C., Stuber, C.W. (1998). "Gene mapping with recombinant inbreds in maize. Genetics, 118, 519-526. 
Carlone, M.R., Jr., Rusell, W.A. (1988). Evaluation of S2 maize lines reproduced for several generations by random mating within lines 1 . Comparison between the original and maintained S2 lines. Crop Sci., 28 (6), 916-920.

Ching, A., Caldwell, K.S., Jung, M., Dolan, M., Smith, O.S., Tingey, S., Morgante, M., Rafalski, A.J. (2002). SNP frequency, haplo-type structure and linkage disequilibrium in elite maize inbred lines. BMC Genetics, 3, 719-733.

Crosbie, T.M., Mock, J.J., Pearce, R. (1978). Inheritance of photosynthesis in a diallel among eight maize inbred lines from lowa Stiff Stalk Synthetic. Euphytica, 27, 675664.

FAO/WHO Expert consultation (1990). FAO/WHO Expert Consultation. Protein Quality Evaluation, FAO/WHO Nutrition Meetings. Report Series 51. Food and Agricultural Organization World Health Organization, Rome.

Fowler, J.E., Freeling, M. (1996). Genetic analysis of mutations that alter cell fates in maize leaves: dominant Liguleless mutations. Dev. Genet., 18, 1998-222.

Gaziola, S.A., Alessi, E.S., Guimarães, P.E.O., Damerval, C., Azevedo, R.A. (1999). Quality protein maize (QPM): A biochemical study of enzymes involved in lysine metabolism. J. Agric. Food Chemistry, 47, 1268-1275.

Hallauer, A.R., Malithano, D., (1976), Evaluation of maize varieties for their potential as breeding populations. Euphytica, 25, 117-127.

Hallauer, A.R., Miranda, J.B. (1988). Quantitative Genetics in Maize Breeding, $2^{\text {nd }}$ edition, lowa State University Press, Ames, IA.

Horner, E.S., Magloire, E., Morera, J.A., (1989). Comparison of selection for S2 progeny vs. testcross performance for population improvement in maize, Crop Sci., 29, 868-874.

Krivanek, A.F., De Groote, H., Gunaratna, N.S., Diallo, A.O., Friesen, D. (2007). Breeding and disseminating quality protein maize (QPM) for Africa. Afr. J. Biotechn., 6 (4), 312324.

Kumar, P., Gupta, V.K., Misra, A.K., Modi, D.R., Pandey, B.K. (2009). Potential of molecular markers in plant biotechnology. Plant Omics J., 2(4), 141-162.

Lee, E.A., Kannenberg, L.W. (2004). Effect of inbreeding method and selection criteria on inbred and hybrid performance. Maydica, 49, 191-197.

Li, M.S., Li, X.H., Salvi, S., Tubeosa, R., Yuan, L.X., Rotondo, F., Bai, L., Zhang, S.H. (2006). Genetic relationships among CIMMYT subtropical QPM and Chinese maize inbred lines based on SSRs. Maydica, 51, 543-549.

Liu, K., Goodma, M., Muse, S., Smith, J.S., Buckler, E., Doebley, J. (2003). Genetic structure and diversity among maize inbred lines as inferred from DNA microsatellites. Genetics, 165, 2117-2128.

Lu, Y., Yan, J., GuimarÃles, C., Taba, S., Hao, Z., Gao, S. (2009). Molecular characterization of global maize breeding germplasm base don genome-wide single nucleotide polymorphisms. Theor. Appl. Genet., 120, 93-115.

Mbuya, K., Nkongolo, K.K., Kalonji-Mbuyi, A., Kizungu, R. (2010). Participatory selection and characterization of quality protein (QPM) varieties in savanna agro-ecological region of DR-Congo. J. Plant Breed. Crop Sc., 2 (11), 325-332.

Mbuya, K., Nkongolo, K.K., Kalonji-Mbuyi, A. (2011). Nutritional Analysis of Quality Protein Maize Varieties selected for agronomic characteristics in a breeding program. Int. J. Plant Breed. Genet, 5 (4), 317-327.

Mehes, M.S., Nkongolo, K.K., Michael, P. (2007). Genetic analysis of Pinus strobus and Pinus monticola populations from Canada using ISSR and RAPD markers: development of genome-specific SCAR markers. Plant Syst. Evol, 267, 47-63.

Melchinger, A.E., Lee, M., Lamkey, K.R., Hallauer, A.R., Woodman, W.L. (1990). Genetic diversity for restriction fragment length polymorphisms and heterosis for two diallel sets of maize inbreds. Theor. Appl. Genet., 80, 488-496. 
Mohammadi, S.A., Prasann, B.M. (2003). Analysis of genetic diversity in crop plants-salient statistical tools and considerations. Crop Sci., 43, 1235-1248.

Musila, R.N., Diallo, A.O., Makumbi, D., Njoroge, K. (2010). Combining ability of earlymaturin quality protein maize inbred lines adapted to Eastern Africa. Field Crop Res, 110 (2-3), 231-23.

Nagaoka, T., Ogihara, Y. (1997). Applicability of inter-simple sequence repeat polymorphisms in wheat for use as DNA markers in comparison to RFLP and RAPD markers. Theor. Appl. Genet., 94, 597-602.

Nkongolo, K.K., Mbuya, K., Mehes-Smith, M., Kalonji-Mbuyi, A. (2011). Molecular analysis of quality protein (QPM) and normal maize varieties from the DR-Congo breeding program. Afr. J. Biotechn., 10 (65), 14293-14301.

Rahman, H., Arifuddin Shah, Z., Ali shah, A.M., Iqbal, M., Khalil, I.H. (2010). Evaluation of maize s2 lines in test cross combinations i: flowering and morphological traits. Pak. J. Bot., 42 (3), 1619-1627.

Reif, J.C., Melchinger, A.E., Xia, X.C., Warburton, M.L., Hoisington, D.A., Vasal, S.K. (2003a). Genetic distance based on simple sequence repeats and heterosis in tropical maize populations. Crop Sci., 43, 1275-1282.

Reif, J.C., Melchinger, A.E., Xia, X.C., Warburton, M.L., Hoisington, D.A., Vasal, S.K. (2003b). Use of SSRs for establishing heterotic groups in subtropical maize. Theor. Appl. Genet., 107, 947-957.

Reif, J.C., Zhang, P., Dreisigacker, S., Warburton, M.L., van Ginkel, M., Hoisington, D. (2005). Wheat genetic diversity trends during domestication and breeding. Theor. Appl. Genet., 110, 859-864.

Remington, D.L., Thornsberry, J.M., Matsuoka, Y., Wilson, L.M., Whitt, S.R. et al. (2001). Structure of linkage disequilibrium and phenotypic associations in the maize genome. Proc. Natl. Acad. Sci. USA., 98, 11479-11484.

Segmagn, K., Magorokosho, C., Vivek, B.S., Makumbi, D, Beyene, Y., Mugo, S, Prasanna, B.M., Warburton, M.L. (2012). Molecular characterization of diverse CIMMYT maize inbred lines from eastern and southern Africa using single nucleotide polymorphism markers. BMC Genomic 13: 113 doi: 10.1186/1471-2164-13-113.

Sofi, P.A., Wani, S., Rather, A.G., Wani, S.H. (2009). Quality protein maize (QPM): Genetic manipulation for nutritional fortification of maize. J. Plant Breed. Crop Sci., 1, 244-253.

Thornsberry, J.M., Goodman, M.M., Doebley, J., Kresovich, S., Nielson, D. et al. (2001). Dwarf 8 polymorphisms associated with variation in flowering time. Nature Genet., 8, 286-289.

Venkatesh, S., Singh, N.N., Gupta, N.P., (2001). Early generation identification and utilization of potential inbred lines in modified single cross hybrids of maize (Zea mays L.). Ind. J. Genet., 61(3), 213-217.

Yeh, F.C., Boyle, T.J.B. (1997), Population genetic analysis of co-dominant and dominant markers and quantitative traits. Belg. J. Bot, 129, 157.

Zietkiewicz, E., Rafalski, A., Labuda, D. (1994). Genome fingerprinting by simple sequence repeat (SSR)-anchored polymerase chain reaction amplification. Genomics, 20, 176183.

(C) 2012 Mbuya et al.; This is an Open Access article distributed under the terms of the Creative Commons Attribution License (http://creativecommons.org/licenses/by/3.0), which permits unrestricted use, distribution, and reproduction in any medium, provided the original work is properly cited. 